Заячківська О. В. [1; ORCID ID: 0000-0002-8792-9204], к.е.н., доцент кафедри фінансів та економічної безпеки

' Національний університет водного господарства та природокористування, м. Рівне

\title{
ОСОБЛИВОСТІ РЕГУЛЮВАННЯ ФІНАНСІВ ЗОВНІШНЬОЕКОНОМІЧНОЇ ДІяЛЬНОСТІ
}

Досліджено основні аспекти правового регулювання зовнішньоекономічної діяльності України та її підприємств. Виявлено проблеми у системі управління та визначено деякі напрями поліпшення ситуації.

Ключові слова: правове регулювання; зовнішньоекономічна діяльність; державне регулювання; правові аспекти.

Постановка проблеми. Політика державного регулювання зовнішньоекономічної діяльності повинна впливати на розвиток зовнішньоекономічних зв'язків України, що буде сприяти зміцненню конкурентоспроможності вітчизняної економіки, їі інноваційному відновленню, а також сприятливому інвестиційному й підприємницькому клімату. Інституційною основою зовнішньоекономічної діяльності $€$ система нормативно-правової поведінки та сукупність інститутів, що виконують функції розробки, забезпечення та контролю за виконанням законодавства.

3 огляду на основні напрямки зовнішньоекономічної та політичної стратегії України, які включають інтеграцію до ЄС та СОТ та лібералізацію відносин національних економічних суб'єктів із іноземними контрагентами, особливе значення має розробка правових основ державного регулювання зовнішньоекономічної діяльності. Це пов'язано з необхідністю зміни принципів функціонування системи державного регулювання зовнішньоекономічної діяльності в Україні та вимогою гармонізації вітчизняного законодавства про неї з відповідними нормативними актами інших країн.

Аналіз останніх досліджень і публікацій показав, що багато досліджень було присвячено правовим питанням регулювання зовнішньої торгівлі в Україні. Так, основні напрями правового регулювання зовнішньоекономічної діяльності детально проаналізовані О.Вишняковим [1], правові основи ведення господарських операцій з іноземними контрагентами та підстави 
відповідальності перед державою за порушення законодавства визначені в працях А. Бузгаліна, Л. Коваль, С. Несінова, А. Омельченко, С. Юшина та ін. [2; 3].

Правове забезпечення зовнішньоекономічної діяльності в Україні здійснюється системою нормативно-правової поведінки, зокрема Конституцією України, Законом України «Про зовнішньоекономічну діяльність», Митним кодексом, Декларацією про державний суверенітет України, загальновизнаними міжнародними нормами та правилами. Однією з основ реалізації державного суверенітету України, відповідно до положень Декларації про державний суверенітет України, є незалежність від здійснення та регулювання зовнішньоекономічних відносин.

Аналізуючи чинне законодавство, можна зробити висновок, що правове регулювання зовнішньоекономічної діяльності в Україні включає зовнішню торгівлю, а також економічне, науково-технічне співробітництво, спеціалізацію та кооперацію у галузі виробництва, науки і техніки, економічні відносини в галузі будівельних, транспортних, експедиторських, страхових, розрахункових, кредитних та інших банківських операцій, що надають різні послуги [4].

Правове закріплення зовнішньоекономічної діяльності міститься в розділі VIII Господарського кодексу України. Проте, безпосередньо різні аспекти зовнішньоекономічних відносин регулюються численною кількістю суперечливих нормативноправових актів, в яких до того ж існують і явні прогалини. Наприклад, визначення зовнішньоекономічної діяльності та господарської діяльності, надані в Господарському кодексі України та Законі України «Про зовнішньоекономічну діяльність» давно вже потребують узгодження по всіх основних ознаках. Вважаємо, що узгодження норм, які залишилися за межами Господарського кодексу, з нормами останнього має істотне значення для покращення правового регулювання сфери зовнішньоекономічної діяльності [5; 6].

Виділення не вирішених раніше частин загальної проблеми. Автором необхідно визначити особливості правового регулювання зовнішньоекономічної діяльності, який є одним з напрямів контролю за її ефективністю.

Виклад основного матеріалу. Як вже зазначалося, зовнішньоекономічна діяльність в Україні, має цілу систему регулювання цих відносин, найважливішими з яких є Закони України «Про зовнішньоекономічну діяльність», «Про захист національного товаровиробника від субсидованого імпорту», «Про застосування 
спеціальних заходів щодо імпорту в Україну» та інші, які, на думку автора, не чітко розмежовують права та обов'язки державних органів, що здійснюють контроль за експортно-імпортними операціями. Тому ці прогалини регулюються на рівні відомчих нормативних актів, що, на думку автора, в більшості випадків захищають інтереси держави, а не сприяють розвитку зовнішньоекономічної діяльності.

Зовнішньоекономічна діяльність у США здійснюється через чітке викладення прав та обов'язків контролюючих органів, які здійснюють нагляд за дотриманням законодавства (наприклад, Міністерство торгівлі згідно з «Торговельним кодексом міжнародної торгівлі»).

Практична придатність законодавства в Україні повинна базуватися на нормативних актах - ще одній галузі права, яка не тільки сприяє розвитку зовнішньоекономічної діяльності, але й захищає інтереси як держави, так і суб'єкта зовнішньоекономічної діяльності. Багато вчених зазначають, що ще не існує чіткої та детальної пропрацьованої зовнішньоекономічної стратегії, держава ще не визначила структурних та географічних пріоритетів, а існуючі регулятивні підходи, включаючи законодавство, не $є$ стимулюючими та підтримуючими.

В інших країнах система законодавчих та адміністративнозаконодавчих регуляторних заходів $€$ ієрархічною пірамідою, яка завершується законом, що веде до комплексного регулювання зовнішньоекономічної діяльності, але в Україні, на жаль, такої системи немає. Невід'ємною частиною зовнішньоекономічного механізму регулювання є тарифна, митна політика держави, яка, серед іншого, служить для захисту внутрішнього ринку та національної безпеки. Однак, стабільності державного митного законодавства в Україні немає.

Так, за Законом України «Про зовнішньоекономічну діяльність», митне регулювання - це регулювання питань, пов'язаних із встановленням мит та інших податків, які справляються в процесі переміщення товарів через митний кордон України, процедурами митного контролю, організацією діяльності органів митного контролю України [4, ст. 1].

Варто відзначити, що митне регулювання зовнішньоекономічної діяльності в Україні проводиться з метою:

- забезпечення збалансованості економіки на внутрішньому ринку України; 
- стимулювання економічних змін, в тому числі у сфері зовнішньоекономічних відносин суб'єктів зовнішньоекономічної діяльності;

- формування сприятливих умов для залучення економіки України в світову економічну систему [7].

На сьогоднішній день митна політика нашої держави характеризується недосконалістю, викликаною значною часткою у загальному обсязі товарообігу товарів, які переміщуються шляхом контрабанди; великою кількістю правопорушень у сфері інтелектуальної власності; невідповідністю діючої системи митного контролю сучасним стандартам пропускної спроможності; наявністю шахрайських і корупційних схем у системі митного регулювання; значним обсягом тінізації зовнішньоекономічної діяльності вітчизняних підприємств тощо [8].

Нестабільність митного законодавства не дозволяє суб'єктам зовнішньоекономічної діяльності ефективно планувати реалізацію економічних інтересів у сфері глобальних економічних відносин. Митне законодавство повинно бути стабільним юридичним документом, здатним одночасно та негайно реагувати на зміни у внутрішній та міжнародній економічній ситуації, але при введенні має існувати певна послідовність. Митна політика України збільшить взаємну довіру та відбудеться зростання кількості вступу до митних союзів із зацікавленими країнами.

Поки Україна йде шляхом лібералізації зовнішньоекономічних відносин та побудови відкритої економічної системи, вона і надалі відчуватиме зростаючий вплив глобальних тенденцій світового розвитку на власні внутрішні економічні процеси.

Тому однією 3 важливих умов успішної та ефективної зовнішньоекономічної діяльності в Україні $€$ створення законодавчої бази, яка відповідатиме часу та вимогам міжнародних дій. Недосконалість нормативних актів негативно впливає на розвиток зовнішньоекономічних відносин країни та призводить до неконтрольованого експорту ресурсів та демпінгових цін на світовому ринку.

Неконтрольованість та відсутність чіткого монетарного регулювання держави, масовий відтік валюти за кордон продовжував привертати увагу провідних фахівців, керівників держави. Звичайно, неналежне регулювання цих та інших відносин, негативно впливає на організацію та здійснення зовнішньоекономічної діяльності, а це значить - і на авторитет нашої держави у зовнішньоекономічних відносинах з іншими державами, іноземного інвестора та приток іноземних інвестицій до неї. 
Беручи до уваги, важливість правового регулювання у цій галузі, слід мати на увазі те, що коли законодавство України буде належним чином врегульовано міжнародною правовою системою, а в деяких випадках і правовою системою, буде спостерігатися набагато більший ефект зовнішньоекономічної діяльності серед країн, що мають найтісніші стосунки з Україною. Це особливо стосується держав-членів СОТ, і з точки зору автора, законодавча гармонія $€$ обов'язковою умовою.

Висновки i пропозиції. Проведене дослідження дозволяє зробити наступні висновки. Політика створення нормативноправового поля зовнішньоекономічної діяльності має враховувати намагання нашої країни інтегруватися у світовий соціальноекономічний простір і необхідність підвищення стабільності й сприятливості вітчизняного законодавства для розвитку відповідних зв'язків. Йдеться про необхідність побудови стабільної, продуманої, узгодженої нормативно-правової бази регулювання зовнішньоекономічної діяльності.

Регулювання зовнішньоекономічної діяльності в Україні здійснюється 3 урахуванням наступних цілей: забезпечення економічного балансу та рівноваги внутрішнього ринку; сприяння поступовим ринковим структурним змінам в економіці; створення сприятливих умов для міжнародного поділу праці, міжнародної економічної інтеграції України та, насамперед, інтеграції до Європейського Союзу.

Таким чином, у процесі комплексної систематизації законодавства про зовнішньоекономічну діяльність на різних етапах слід використовувати такі форми систематизації, як консолідація та кодифікація. При цьому, крім систематизації як форми упорядкування законодавства, слід використовувати ревізію законодавства про зовнішньоекономічну діяльність, що дасть змогу «розчистити» та впорядкувати цей нормативний масив.

1. Вишняков А.К. Регулирование внешнеэкономической деятельности в Украине. Х. : 000 «Одиссей», 2005. 256 с. 2. Омельченко А. Шляхи вдосконалення та розвитку законодавства України про зовнішньоекономічну діяльність. Право України. 2011. № 6. С. 23-29. 3. Юшина С. І. Сучасний стан та деякі колізії правового регулювання зовнішньоекономічної діяльності в Україні. Вісник господарського судочинства. 2009. № 1. С. 54-58. 4. Про зовнішньоекономічну діяльність : Закон України від 16.04.1991 №959-XII, із змінами. URL: https://zakon.rada.gov.ua/laws/show/959-12\#Text (дата звернення: 14.12.2020). 5. Сластьоненко 0. О., Воробей О.С. Правове регулювання фінансових відносин у ЗЕД: проблеми та перспективи розвитку. Актуальні проблеми забезпечення безпеки та спрощення процедур міжнародної торгівлі : зб. тез III науково-практичної інтернет-конференції (17-24 травня 2019 року). Ірпінь ; Хмельницький. 2019. С. 26- 
28. 6. Господарський кодекс України : Закон України від 16.01.2003 № 436-IV, із змінами. URL: https://zakon.rada.gov.ua/laws/show/436-15\#Text (дата звернення: 14.12.2020). 7.Гуменюк О.Г. До питання про основні принципи митного регулювання зовнішньоекономічної діяльності. Науковий вісник Херсонського державного університету. 2016. № 16 (4). С. 113-116. 8. Голинський Ю. О., Муляр В.В. Митна політика та їі вплив на менеджмент зовнішньоекономічної діяльності. Молодий вчений. 2018. № 10(2). С. 745-748.

\section{REFERENCES:}

1. Vyshniakov A. K. Rehulyrovanye vneshneэkonomycheskoi deiatelnosty $v$ Ukrayne. Kh. : 000 «Odyssei», 2005. 256 s. 2. Omelchenko A. Shliakhy vdoskonalennia ta rozvytku zakonodavstva Ukrainy pro zovnishnoekonomichnu diialnist. Pravo Ukrainy. 2011. № 6. S. 23-29. 3. Yushyna S. I. Suchasnyi stan ta deiaki kolizii pravovoho rehuliuvannia zovnishnoekonomichnoi diialnosti $v$ Ukraini. Visnyk hospodarskoho sudochynstva. 2009. № 1. S. 54-58. 4. Pro zovnishnoekonomichnu diialnist : Zakon Ukrainy vid 16.04.1991 № 959-XII, iz zminamy. URL: https://zakon.rada.gov.ua/laws/show/959-12\#Text (data zvernennia: 14.12.2020). 5. Slastonenko 0. 0., Vorobei 0. S. Pravove rehuliuvannia finansovykh vidnosyn u ZED: problemy ta perspektyvy rozvytku. Aktualni problemy zabezpechennia bezpeky ta sproshchennia protsedur mizhnarodnoi torhivli : zb. tez III naukovo-praktychnoi internetkonferentsii (17-24 travnia 2019 roku). Irpin ; Khmelnytskyi. 2019. S. 26-28. 6. Hospodarskyi kodeks Ukrainy : Zakon Ukrainy vid 16.01.2003 № 436-IV, iz zminamy. URL: https://zakon.rada.gov.ua/laws/show/436-15\#Text (data zvernennia: 14.12.2020). 7. Humeniuk O. H. Do pytannia pro osnovni pryntsypy mytnoho rehuliuvannia zovnishnoekonomichnoi diialnosti. Naukovyi visnyk Khersonskoho derzhavnoho universytetu. 2016. № 16 (4). S. 113-116. 8. Holynskyi Yu. O., Muliar V. V. Mytna polityka ta yii vplyv na menedzhment zovnishnoekonomichnoi diialnosti. Molodyi vchenyi. 2018. № 10(2). S. 745-748.

Zaiachkivska O. V. [1; 0RCID ID: 0000-0002-8792-9204], Candidate of Economics (Ph.D.), Associate Professor of the Department of Finance and Economic Security

${ }^{1}$ National University of Water and Environmental Engineering, Rivne

\section{FEATURES OF FINANCE REGULATION OF FOREIGN ECONOMIC ACTIVITY}

The main aspects of legal regulation of foreign economic activity of Ukraine and its enterprises are studied. Problems in the management system have been identified and some areas for improvement have been identified. The policy of state regulation of foreign economic activity should influence the development of Ukraine's foreign economic relations, which will help strengthen the competitiveness of the domestic economy, its innovative recovery, as well as a favorable investment and business climate. The institutional basis of foreign economic activity is a system of regulations 
and a set of bodies that perform the functions of creating, implementing and monitoring the implementation of legislation. Legal support of foreign economic activity in Ukraine is carried out by a system of normative legal acts, in particular the Constitution of Ukraine, the Law of Ukraine «On Foreign Economic Activity», the Customs Code, the Declaration of State Sovereignty of Ukraine, generally recognized international norms and rules. In accordance with the provisions of the Declaration of State Sovereignty of Ukraine, one of the foundations of the implementation of the state sovereignty of Ukraine is its independence in the implementation and regulation of foreign economic relations. The study allows us to draw the following conclusions. The policy of creating a regulatory framework for foreign economic activity should take into account the efforts of our country to integrate into the global socio-economic space and the need to increase the stability and favorable domestic legislation for the development of relevant ties. It is a question of necessity of construction of stable, thoughtover, coordinated normative-legal base of regulation of foreign economic activity. Thus, in the process of comprehensive systematization of legislation on foreign economic activity at different stages should use such forms of systematization as consolidation and codification. In this case, in addition to systematization as a form of streamlining legislation, should also use the revision of legislation on foreign economic activity, which will "clear" and streamline this regulatory array.

Keywords: legal regulation; foreign economic activity; state regulation; legal aspects.

Заячкивская О. В. ${ }^{[1 ; 0 R C I D ~ I D: ~ 0000-0002-8792-9204], ~}$ к.э.н., доцент кафедры финансов и экономической безопасности

${ }^{1}$ Национальный университет водного хозяйства и природопользования, г. Ровно

\section{ОСОБЕННОСТИ РЕГУЛИРОВАНИЯ ФИНАНСОВ ВНЕШНЕЭКОНОМИЧЕСКОЙ ДЕЯТЕЛЬНОСТИ}

Исследованы основные аспекты правового регулирования
внешнеэкономической деятельности Украины и ее предприятий.
Выявлены проблемы в системе управления и определены некоторые
направления улучшения ситуации. Политика государственного
регулирования внешнеэкономической деятельности должна влиять на
развитие внешнеэкономических связей Украины, что будет
способствовать укреплению конкурентоспособности отечественной
экономики, ее инновационному восстановлению, а также
благоприятному инвестиционному и предпринимательскому климату.
Институциональной основой внешнеэкономической деятельности
выступают система нормативно-правовыхактов и совокупность органов,


выполняющих функции создания, реализации и контроля выполнения законодательства. Правовое обеспечение внешнеэкономической деятельности в Украине осуществляется системой нормативно-правовых актов, в частности Конституцией Украины, Законом Украины «0 внешнеэкономической деятельности», Таможенным кодексом, Декларацией о государственном суверенитете Украины, В целом признанными международными нормами и правилами. В соответствии с положениями Декларации о государственном суверенитете Украины, одной из основ реализации государственного суверенитета Украины является ее независимость в осуществлении и регулировании внешнеэкономических отношений. Проведенное исследование позволяет сделать следующие выводы. Политика создания нормативно-правового поля внешнеэкономической деятельности должна учитывать попытки нашей страны интегрироваться в мировое социально-экономическое пространство и необходимость повышения стабильности и благоприятности отечественного законодательства для развития соответствующих связей. Речь идет о необходимости построения стабильной, продуманной, согласованной нормативно-правовой базы регулирования внешнеэкономической деятельности. Таким образом, в процессе комплексной систематизации законодательства о внешнеэкономической деятельности на разных этапах следует использовать такие формы систематизации, как консолидация и кодификация. При этом, кроме систематизации как формы упорядочения законодательства, следует использовать также ревизию законодательства о внешнеэкономической деятельности, что позволит «расчистить» и упорядочить этот нормативный массив.

Ключевые слова: правовое регулирование; внешнеэкономическая деятельность; государственное регулирование; правовые аспекты. 